\title{
TINDAK TUTUR PERLOKUSI \\ DALAM NOVEL INDIGO STORIES KARYA HANAMIZUKI MEGA
}

\author{
(Perlocution in Hanamizuki Mega's Indigo Stories)
}

\author{
Ferdian Achsani \\ SMPN 1 Weru \\ J1. Kapten Pattimura 03, Karangmojo, Weru, Sukoharjo, Jawa Tengah \\ Pos-el: dwikurniawan219@gmail.com
}

(Naskah Diterima 27 Februari 2021-Direvisi 9 Maret 2021-Disetujui 12 Maret 2021)

\begin{abstract}
This study aims to describe the form of perlocutionary speech acts found in the novel Indigo Stories. Thi is a qualitative descriptive research. The process of obtaining data was carried out through a documentation study which included reading techniques. The writer reads the novel over and over again and marks the parts of the dialogue that show it as a form of perlocutionary speech act using Searle's speech act theory. The results showed that there were several perlocutionary utterances in the Indigo Stories, such as representative, directive, expressive, commissive and declarative speech. The results showed that the most dominant type of speech found was directive which was marked by data findings of $37.86 \%$. The type of directive speech that is mostly found is the form of speech to ask. Meanwhile, the least number of speeches found was the type of declarative speech, which was indicated by data findings of 6.25\%. In this type of speech, only prohibiting speech forms are found.
\end{abstract}

Keywords: speech acts, locus, novel

\begin{abstract}
Abstrak
Penelitian ini bertujuan untuk mendeskripsikan bentuk tindak tutur perlokusi yang terdapat pada novel Indigo Stories. Penelitian ini termasuk penelitian deskriptif kualitatif. Pengumpulan data dilakukan melalui studi dokumentasi dengan teknik baca. Penulis membaca novel secara berkali-kali dan menandai bagian-bagian dialog yang menunjukkan sebagai bentuk tindak tutur perlokusi dengan menggunakan teori tindak tutur Searle. Hasil penelitian menunjukkan bahwa ditemukan beberapa bentuk tuturan perlokusi pada novel Indigo Stories, seperti tuturan representatif, direktif, ekspresif, komisif, dan deklaratif. Hasil penelitian menunjukkan bahwa jenis tuturan yang paling dominan ditemukan adalah direktif, yaitu sebanyak $37,86 \%$. Jenis tuturan direktif yang paling banyak ditemukan adalah bentuk tuturan meminta. Sementara itu, tuturan yang paling sedikit ditemukan adalah jenis tuturan deklaratif, yaitu sebanyak $6,25 \%$. Pada jenis tuturan ini hanya ditemukan bentuk tuturan melarang.
\end{abstract}

Kata kunci: tindak tutur, pelokusi, novel

\section{PENDAHULUAN}

Komunikasi merupakan aspek terpenting dalam kehidupan karena merupakan proses interaksi dengan sesama manusia. Komunikasi dapat diartikan sebagai proses mengirimkan pesan dari penutur kepada kawan tuturnya. Sari \& Irma (2020: 47) menegaskan bahwa komunikasi adalah pertukaran informasi dari individu kepada individu yang lain dengan menggunakan media bahasa atau lambang. Dapat diketahui bahwa media yang diperlukan untuk berlangsungnya 
proses komunikasi salah satunya adalah bahasa. Bahasa menjadi salah satu alat yang digunakan untuk berinteraksi, menuangkan gagasan, ide, pendapat, dan sebagainya. Peran bahasa sangat penting sebagai alat untuk menunjang keberlangsungan proses komunikasi. Dengan adanya bahasa, sender (pengirim) dapat mengirimkan pesan kepada receiver (penerima) dengan baik. Dengan adanya bahasa pula tujuan komunikasi dapat berjalan dengan lancar (Achsani \& Hilmi, 2018).

Penggunaan bahasa sebagai alat komunikasi dapat berupa lisan atau tertulis. Komunikasi lisan merupakan komunikasi yang dituturkan langsung oleh penutur kepada mitra tutur pada suatu peristiwa tutur. Proses komunikasi yang demikian dapat ditemui ketika mendengarkan ceramah keagamaan, debat, pidato, dan sebagainya. Pembicara melakukan komunikasi dengan audiensi secara langsung dengan bertutur kata. Kegiatan yang demikian dinamakan sebagai komunikasi langsung karena adanya tatap muka antara pembicara (penutur) dan yang diajak bicara.

Selain komunikasi lisan ada juga komunikasi tertulis. Komunikasi tertulis merupakan proses komunikasi yang dilakukan oleh seseorang yang dilakukan secara tertulis dengan penggunaan bahasa atau dengan simbol-simbol tertentu. Polanda \& Putri, (2020: 34) mengutip pendapat Retno dkk yang menguraikan bahwa proses komunikasi tertulis disusun dengan kalimat-kalimat yang terstruktur sehingga mengandung pesan. Proses komunikasi seperti ini dapat dilakukan secara jarak jauh. Artinya, dalam berkomunikasi pengirim atau penutur tidak perlu bertatap muka secara langsung dengan audiensi atau kawan tutur atau komunikan. Proses komunikasi secara tertulis dapat ditemui di karya sastra, pesan WA, koran, atau yang lainnya.
Novel merupakan bentuk karya sastra yang berisikan pesan yang ingin disampaikan oleh penulis kepada pembaca. Putra dkk, (2020: 162) menjelaskan bahwa novel merupakan bentuk karya sastra yang panjang dan kompleks dengan cerita yang didasarkan pada pengalaman pribadi penulis. Pengamalaman atau persoalan pribadi penulis tersebut didasari adanya persoalan sosial yang dialami penulis di lingkungannya (Sultoni, Achmad \& Kaleb, 2020: 108). Melalui karya sastra novel, secara tidak langsung penulis ingin berkomunasi dengan pembaca, yaitu ingin bercerita mengenai apa yang dirasakan dan dipikirkannya. Dalam proses komunikasi tersebut penulis ingin bercerita untuk menghibur pembaca dan membagikan pengalaman yang digagasnya. Tidak sekadar menghibur, proses komunikasi yang dilakukan oleh penulis melalui karya sastra novel ini salah satunya untuk memberikan nilai didik atau memberikan amanat atau pesan, baik yang tersurat dan tersirat kepada pembaca. Setiap karya sastra diciptakan dengan tujuan untuk memberikan nilai didik kepada pembaca. Hal inilah yang menjadi alasan bahwa salah satu proses komunikasi yang terdapat pada novel salah satunya adalah untuk memberikan nilai didik kepada pembaca (Rahmawati \& Ferdian, 2019: 54).

Bentuk komunikasi yang berjalan pada suatu karya sastra novel tidak selalu dengan pendeskripsian cerita. Adanya dialog antartokoh dalam karya sastra novel juga dapat dikatakan sebagai bentuk komunikasi. Dialog atau percakapan dalam novel merupakan interaksi antartokoh yang memiliki awal dan akhir serta maksud dan tujuan tertentu (Tamrin \& Nursyamsi, 2020: 20). Perlunya dialog dalam karya sastra novel ditujukan kepada pembaca agar dapat mengetahui perasaan yang 
terbangun. Dialog percakapan antartokoh dalam karya sastra novel secara tidak langsung mengajak pembaca terjun dan merasakan sekaligus ikut menyaksikan dan terlibat dalam proses komunikasi. Dialog yang tergambar melalui percakapan antartokoh tersebut merupakan bentuk tiruan kehidupan manusia pada umumnya. Percakapan antartokoh tersebut memungkinkan untuk dikaji dalam bentuk tindak tuturnya (Huwaida et al., 2020: 78).

Dalam proses dialog komunikasi pada karya sastra novel tersebut pula dapat diketahui bentuk-bentuk tindak tutur atau ujaran yang disampaikan oleh setiap tokoh. Tindak tutur merupakan salah satu kajian dalam cabang ilmu pragmatik yang bertujuan untuk memahami maksud dan tujuan dari sebuah tuturan pada suatu situasi tutur. Tindak tutur merupakan proses komunikasi yang berlangusng antara penutur dan kawan tutur yang mengharapkan adanya hubungan timbal balik dari keduanya. Untuk itu, tindak tutur tidak dapat berlangsung apabila tidak terdapat penutur dan kawan tutur. Proses tindak tutur tersebut terjadi secara alamiah tanpa adanya setingan.

Nursiah \& Siti (2020: 74) mengungkapkan bahwa tindak tutur merupakan proses komunikasi yang terjadi secara alami. Setiap tuturan yang disampaikan oleh seseorang mempunyai maksud dan tujuan tertentu yang memiliki pengaruh kepada lawan tuturnya. Umamy \& Cintya (2020) menambahkan bahwa tindak tutur bersifat psikologis dan bergantung pada kemampuan berbahasa seseorang. Background atau latar belakang penutur dan kawan tutur sangat memengaruhi hasil komunikasi. Marwuni \& Asep (2020: 24) mengatakan bahwa dalam tindak tutur yang dilihat adalah makna dari tindakan yang dilakukannya.
Dalam kajian pragmatik, Searle membagi bentuk tuturan seseorang menjadi tiga bentuk, yaitu tindak tutur lokusi, ilokusi, dan perlokusi (Wijana \& Muhammad, 2011). Tindak tutur lokusi merupakan suatu tuturan yang berfungsi untuk menyatakan sesuatu. Tindak tutur ilokusi merupakan tindak tutur yang berfungsi untuk mengatakan atau menginformasikan sesuatu kepada mitra tutur. Tindak tutur perlokusi merupakan tuturan yang berfungsi untuk memengaruhi mitra tutur. Selanjutnya Searle (dalam Kurniati, 2020) mengklasifikasikan bentuk tindak tutur dalam lima bentuk, yaitu direktif, ekspresif, asertif, komisif, dan representatif. Setiap tuturan tersebut memiliki definisi dan bentuk tuturan yang berbeda sesuai dengan maksud dan tujuan masing-masing.

Penelitian ini bertujuan untuk mendeskripsikan bentuk tindak tutur perlokusi yang terdapat pada novel Indigo Stories. Setiap tuturan yang disampaikan, baik oleh penutur maupun kawan tutur tentu memiliki efek tertentu. Hal ini merupakan pengertian dari tindak tutur perlokusi (Astuti \& Ira, 2016: 103). Tuturan yang disampaikan oleh penutur diharapkan dapat memberikan efek berupa tindakan nyata. Maksudnya, tuturan yang disampaikan oleh penutur tersebut dapat direspons dengan baik oleh kawan tuturnya sesuai dengan maksud dan tujuan tuturan. Dengan demikian, proses komunikasi berjalan dengan baik dan tercipta prinsip kerja sama dalam berkomunikasi. Sari mengungkapkan bahwa tuturan perlokusi ini dikreasikan oleh penutur secara sengaja dan dapat pula tanpa disengaja (Sari, 2014).

Indigo Stories merupakan salah satu novel bergenre horor yang sedang booming. Dikatakan sedang booming karena di Wattpad novel ini telah dibaca sebanyak 1,8 miliar kali. Hal ini 
disebabkan oleh masyarakat Indonesia saat ini sedang menyenangi cerita-cerita mistis atau horor. Membaca cerita horor menjadi hobi baru bagi generasi milenial saat ini karena dapat memberikan kepuasan batin bagi pembaca. Ceritacerita horor tersebut booming karena isinya dekat dengan kehidupan masyarakat dan bahkan sebagian dari pembaca pernah mengalami sendiri halhal tersebut (Puspasari, 2020). Indigo Stories merupakan salah satu novel yang tidak hanya dapat dinikmati melalui cetakan dalam bentuk buku, tetapi juga digital. Cerita yang diangkat dalam novel ini berisi pengalaman pribadi penulis yang dapat berinteraksi dengan makhluk halus.

Penulis tidak hanya berbagi pengalaman, tetapi juga ingin memberikan informasi kepada pembaca bahwa menjadi indigo bukanlah kelebihan yang menyenangkan. Penulis mengisahkan bahwa banyak hal negatif yang dialami seorang indigo, seperti diganggu oleh makhluk halus yang jahil dan menyeramkan dan tersitanya waktu tidur. Hal-hal tersebut diungkapkan sendiri oleh penulis dalam novel ini.

Penelitian yang relevan pernah dilakukan oleh Marini dan Rizki (2021). Mereka mengkaji novel Guru Aini karya Andrea Hirata. Dalam penelitiannya Marini dan Rizki mengkaji bentukbentuk tuturan ilokusi pada novel tersebut. Hasil penelitian menunjukkan bahwa tuturan dialog yang disampaikan antartokoh pada novel Guru Aini berupa bentuk tuturan ilokusi yang meliputi tuturan asertif, direktif, ekspresif, komisif, dan deklaratif. Setiap tuturan ilokusi yang disampaikan para tokoh tersebut memiliki fungsi sesuai dengan bentuk masing-masing. Adanya tuturan ilokusi pada dialog novel ini menjadikan jalinan cerita yang utuh.

Penelitian yang dilakukan oleh Sanyya dkk. (2020) dalam mengkaji kalimat imperatif pada caption akun "Teladan Rasul" di Instagram dapat dikatakan relevan dengan penelitian ini. Kalimat imperatif merupakan kalimat yang berfungi untuk meminta atau memerintah lawan tutur sesuai dengan kehendak penutur dan memiliki makna yang bervariasi. Menurutnya, kalimat imperatif merupakan jenis tuturan yang digunakan masyarakat sebagai penunjang keberhasilan dalam penyampaian makna dan tuturan dalam berkomunikasi. Penelitian tersebut menyimpulkan bahwa tuturan imperatif dalam caption akun "Teladan Rasul" memiliki fungsi yang secara keseluruhan mengingatkan netizen terhadap hal-hal yang baik sesuai dengan anjuran agama. Selain itu, hasil penelitian ini dapat digunakan sebagai bahan ajar pemelajaran Bahasa Indonesia pada materi teks prosedur dan menambah keterampilan berbahasa siswa mengenai bentuk tuturan imperatif.

\section{METODE PENELITIAN}

Penelitian ini termasuk jenis deskriptif kualitatif yang mendeskripsikan hasil temuan data berupa uraian kata-kata atau kalimat. Objek pada penelitian ini ialah novel Indigo Stories karya Hanamizuki Mega yang diterbitkan oleh Coconut Book pada tahun 2018 (cetakan keempat). Novel tersebut dipilih karena merupakan salah satu novel bergenre horor yang sangat populer di Wattpat. Pengumpulan data dilakukan dengan teknik studi pustaka. Peneliti membaca novel tersebut secara berulang dan menandai bagian-bagian dialog percakapan antartokoh yang menunjukkan tindak tutur perlokusi.

Teknik analisis data dalam penelitian ini menggunakan analisis interaktif. Proses analisis dilakukan melalui tahap pengumpulan data, reduksi data, penyajian data, dan penarikan 
simpulan. Pengumpulan data dilakukan dengan membaca dan menandai dialogdialog yang terdapat dalam novel tersebut. Data yang sudah terkumpul selanjutnya direduksi, yaitu memilih dan memilah data yang termasuk tindak tutur perlokusi. Tahapan selanjutnya adalah penyajian data, yaitu dengan menyajikan hasil analisis. Langkah terakhir adalah penarikan simpulan.

\section{PEMBAHASAN}

Pada bagian ini akan dipaparkan temuan data sekaligus pembahasannya. Terdapat lima bentuk tindak tutur perlokusi yang meliputi tindak tutur representatif, direktif, ekspresif, komisif, dan deklaratif. Berdasarkan hasil analisis yang sudah dilakukan, peneliti menemukan 240 tuturan kalimat perlokusi yang terdapat dalam novel Indigo Stories. Sebenarnya masih banyak tuturan perlokusi yang terdapat dalam novel ini. Akan tetapi, peneliti tidak mengambil semua tuturan tersebut. Jumlah tuturan tersebut dapat dilihat pada tabel di bawah ini.

Tabel 1

Persentase Hasil Temuan

\begin{tabular}{ll}
\multicolumn{1}{c}{ Jenis Tuturan } & \multicolumn{1}{c}{ Presentase } \\
\hline Representatif & $36,76 \%$ \\
\hline Direktif & $37,86 \%$ \\
\hline Ekspresif & $10,29 \%$ \\
\hline Komisif & $8,82 \%$ \\
\hline Deklaratif & $6,25 \%$ \\
\hline
\end{tabular}

Tabel di atas merupakan hasil perhitungan temuan data dalam hitungan persen. Tabel di atas menunjukkan bahwa bentuk tuturan representatif sebanyak 36,76\%, direktif $37,86 \%$, ekspresif $10,29 \%$, komisif $8,82 \%$, dan deklaratif $6,25 \%$.

\section{Representatif}

Representatif merupakan tuturan yang menyatakan suatu peristiwa atau keadaan sesuai dengan kebenaran oleh penutur (Searle dalam Kurniati, 2020). Tuturan ini ditandai dengan beberapa bentuk tuturan, seperti mengakui, menyatakan, menunjukkan, melaporkan, dan menuntut. Dalam novel Indigo Stories tuturan representatif merupakan bentuk tuturan yang paling dominan. Hal ini dapat dilihat dari jumlah data yang mencapai $41,66 \%$. Tuturan representatif yang paling banyak ditemukan ialah bentuk menyatakan dan mengakui. Tuturan yang paling sedikit ditemukan adalah tuturan menuntut.

\section{Mengakui}

"Aku tidak berbuat apa-apa. Tapi waktu kita di pohon beringin kembar, aku menemukan sebuah benda kecil yang bentuknya mirip keris. Aku pikir itu benda kuno, makanya kuambil," ungkap Dimas (Mega, 2019).

Kutipan di atas merupakan bentuk tindak tutur mengakui. Dalam kutipan tersebut Dimas mengakui bahwa dia mengambil benda kuno yang berbentuk seperti keris ketika sedang berlibur di pohon beringin kembar di Yogyakarta. Keris yang diambilnya tersebut ternyata ada penunggunya. Penunggunya selalu menampakkan diri pada Dimas, meminta keris dikembalikan. Dimas yang merasa ketakutan bercerita dan meminta bantuan kepada Agni. Tuturan mengakui yang disampaikan Dimas tersebut merupakan bentuk tindak tutur perlokusi. Tuturan tersebut memiliki efek kepada lawan tutur, Agni, agar mau membantunya untuk menyelesaikan masalah yang tengah dihadapinya.

"Kalau tidak dibohongi seperti itu, kamu takkan mau datang," Sahut Yoga (Mega, 2019: 37). 
Penasaran terhadap hal-hal yang tidak kasat mata adalah salah satu kesukaan manusia. Hal itu dituliskan dalam novel ini. Awalnya Panca dan Yoga merayu Agni untuk melakukan ekspedisi malam hari di sekolah dan berharap bisa bertemu dengan hantu penunggu sekolah. Agni menolak hal tersebut karena harus menyelesaikan tugas rumah. Yoga dan Panca tidak tinggal diam. Mareka pun mengatur siasat dengan meminta bantuan kepada Ridwan dan Rossy untuk membohongi Agni. Mereka meminta Agni untuk membimbing agenda jurit malam yang diselenggarakan oleh OSIS dalam rangka melatih para junior. Ternyata Agni hanya dibohongi oleh Ridwan dan Rossy. Ia pun sadar kalau itu hanya akalakalan Yoga. Tuturan di atas merupakan bentuk tindak tutur representatif mengakui. Hal yang diakui dalam tuturan di atas adalah Yoga yang membohongi Audy dengan efek agar Agni mau mengikutinya untuk melakukan ekspedisi malam hari di sekolah.

\section{Menyatakan}

"Dulu kamu memang paling cantik, tapi sekarang wajahmu kelihatan mengenaskan. Matamu biru, wajah bengkak seperti orang kena pukul. Wajahmu sekarang tak beraturan, tak cantik lagi," aku menunjuk dengan detail setiap luka di wajahnya (Mega, 2019: 257).

Tindak tutur representatif juga ditunjukkan kutipan di atas. Kutipan tersebut berisi pernyataan Agni mengenai sosok hantu bernama Ning. Hantu tersebut sering menganggu Agni ketika bekerja. Salah satunya si hantu pernah meminta pendapat kepada Agni tentang kecantikan yang dimilikinya. Agni menjawab dengan pernyataan bahwa dulu ketika dia masih hidup memang cantik, tetapi sekarang setelah menjadi hantu, wajah Ning sudah jauh dari kata cantik. Tuturan Agni tersebutlah yang mengandung bentuk tindak tutur perlokusi menyatakan. Tuturan pernyataan yang disampaikan oleh Agni tersebut memiliki efek kepada lawan tutur agar merasa lega. Dengan tuturan yang disampaikanya tersebut ia berharap Ning bisa melihat keadaannya yang sekarang.

"Sebab saya indigo, Bu. Memang ini sulit untuk dijelaskan, tapi saya mohon sekali ini saja, Bu. Tolong Audy dan juga saya," (Mega, 2019: 29).

Tuturan di atas merupakan bentuk perlokusi menyatakan. Dalam tuturan tersebut Agni menyatakan kepada $\mathrm{Bu}$ Minarti bahwa ia adalah anak indigo atau memiliki keistimewaan melihat halhal yang tidak kasat mata. Ia mengaku demikian sebab ingin membantu Audy untuk memberikan pesan kepada ibunya tersebut. Bu Minarti adalah ibu Audy. Sudah lama Audy ingin berbicara dengan ibunya. Ia menitipkan pesan kepada ibunya di dalam sebuah buku, tetapi tidak ada yang bisa membantunya. Beruntung ia bertemu dengan Audy dan mau menolongnya untuk menyampaikan pesan kepada ibunya tersebut. Tuturan pernyataan yang disampaikan oleh Agni tersebut memiliki efek agar Bu Minarti memercayainya sebagai anak indigo sehingga dia bisa membantu Audy untuk menyampaikan pesan kepada ibunya tersebut.

\section{Menunjukkan}

Aku masih tertawa beberapa menit. Berbarengan dengan suara tertawa si kunti. "Berat tidak usah cari siapa ini yang melempar. Jauh soalnya."

Bapakku masih heran. "Maksudnya apa?"

Aku menunjuk ke pohon tempat si kunti itu duduk. "Yang lemparin batu ada di sana," aku tersenyum lebar (Mega, 2019: 437). 
Tindak tutur representatif juga ditunjukkan dalam kutipan di atas. Kutipan tersebut berisi tuturan menunjukkan. Agni menunjukkan kepada bapaknya mengenai sosok yang melempari mereka dengan batu. Konteks tuturan tersebut terjadi ketika tengah malam ayah Agni menjemputnya pulang kerja. Di tengah jalan justru ban motor yang dikendarainya bocor. Agni dan bapaknya terpaksa menuntun sepeda motor. Ketika sedang menuntun sepeda motor, mereka dilempari batu oleh sosok kuntilanak yang sedang duduk di atas pohon. Agni pun menunjukkan letak hantu tersebut kepada bapaknya. Tuturan Agni inilah yang mengandung tindak tutur representatif menunjukkan. Agni menunjukkan sosok kuntilanak yang tengah melempari mereka dengan batu. Tuturan ini memiliki efek, yaitu agar ayahnya mengetahui keberadaan sosok kuntilanak itu.

"Di samping sepi, woi! Aku baru masuk toilet nih," aku mulai geram (Mega, 2019: 21).

Tuturan di atas termasuk bentuk tindak tutur perlokusi menunjukkan. Ketika Agni sedang berganti baju olahraga, tiba-tiba pintu kamar mandinya diketuk oleh seseorang dari luar yang ternyata adalah hantu Audy. Agni mengira bahwa itu adalah manusia biasa sehingga ia menunjukkan kepada orang tersebut bahwa kamar mandi sebelah kosong. Agni menunjukkan bahwa ia baru saja masuk kamar mandi dan menunjukkan bahwa kamar mandi sebelah kosong sehingga tidak perlu mengetuk pintu kamar mandi yang tengah dipakai Agni. Tuturan yang disampaikan oleh Agni mengandung efek agar orang tersebut mau menggunakan kamar mandi di sebelah.

\section{Direktif}

Tuturan direktif adalah bentuk tuturan yang meminta lawan tutur untuk melakukan suatu perbuatan sesuai dengan yang dimaksudkan oleh penutur (Searle dalam Kurniati, 2020). Bentuk tuturan itu ditandai dengan pernyataan meminta, mengajak, memaksa, menyarankan, memohon, dan menantang. Dalam novel Indigo Stories, data jenis ini mencapai 33,33\%. Hampir semua tuturan yang disebutkan sebelumnya muncul pada novel ini. Tuturan yang paling banyak ditemukan adalah meminta, sedangkan yang paling sedikit ditemukan adalah menantang.

\section{Meminta}

"Tetap rekam gambarnya, sampai dapat sosok hantu yang kita cari. Ayo Ridwan!" seru Yoga (Mega, 2019: 42).

Tuturan di atas merupakan bentuk tindak tutur direktif. Tuturan direktif tersebut dapat dilihat dari isi tuturan Tetap rekam gambarnya yang disampaikan oleh Yoga. Efek dari tuturan tersebut adalah Ridwan merekam perjalanan ekspedisi malam mereka di sekolah. Dalam tuturan tersebut Yoga meminta Ridwan untuk tetap fokus mengambil gambar agar tidak ada yang terlewat. Konteks tuturan tersebut terjadi ketika Yoga dkk. melakukan ekspedisi malam untuk mengetahui sosok hantu penunggu sekolah. Yoga memberikan tugas kepada Ridwa untuk merekam gambar agar gambar tersebut bisa dijadikan bukti untuk teman-teman sekolahnya.

"Lotengnya ditutup saja ya, Pak, biar aku tidak bisa main di sana terus. Perasaan ibu nggak enak, pas ibu lihat ke atas ibu langsung merasa merinding takutnya Agni main sama makhluk halus." (Mega, 2019: 8) 
Ketika masih kecil, Agni suka bermain di atas loteng dengan hantu-hantu penunggu di sana. Hal tersebut membuat ibunya khawatir dan takut sebab Agni masih kecil dan takut jika terjadi hal-hal yang tidak diinginkan. Ibunya pun meminta kepada ayahnya untuk menutup loteng tersebut. Tuturan yang disampaikan oleh ibu Agni tersebut mengandung bentuk tindak tutur meminta. Hal ini dapat dilihat pada kalimat Lotengnya ditutup saja ya, Pak. Ibu Agni meminta suaminya menutup loteng tersebut. Efek yang dihasilkan dari tuturan tersebut adalah suaminya menuruti perintah istrinya untuk menutup loteng agar Agni tidak bisa lagi bermain dengan hantu-hantu yang ada di sana.

\section{Menyarankan}

Aku mengangguk. "Tapi Agni mohon sama mas Ridwan, jangan kasih tahu ibu sama bapak, yah."

Dia mengangguk. "Tapi lain kali, jangan suka mencampuri urusan orang lain lagi. Jika melihat makhluk halus, jangan suka berkomunikasi dengan mereka. Karena tidak semua dari mereka itu mempunyai energi yang positif." (Mega, 2019: 107).

Pada kutipan di atas terdapat dua tuturan perlokusi direktif yang dimunculkan para tokoh. Tuturan direktif yang muncul pada kutipan di atas ialah memohon dan menyarankan. Tuturan memohon ditunjukkan oleh tokoh Agni yang memohon kepada Ridwan untuk merahasiakan apa yang sudah dilihatnya di rumah Pak Ustaz dan memintanya untuk tidak melaporkannya kepada kedua orang tuanya. Efek yang dihasilkan dari tuturan Agni ialah Ridwan mau merahasiakan hal yang sudah dilihatnya di rumah Pak Ustaz kepada siapa pun. Sementara itu, tuturan menyarankan ditunjukkan melalui tokoh Mas Ridwan yang menyarankan Agni untuk tidak sembarangan mencampuri urusan orang lain dan tidak berkomunikasi dengan makhluk halus lain karena itu bukanlah hal yang baik. Mencampuri urusan orang lain bukanlah perilaku yang baik, apalagi menyangkut masalah spiritual. Untuk itu, tuturan Mas Ridwan tersebut mempunyai efek kepada Agni, yaitu tidak lagi mencampuri urusan orang lain serta tidak sembarangan berkomunikasi dengan makhluk selain manusia.

"Harusnya kamu bersyukur tidak bisa melihat mereka. lebih baik jaga ucapanmu itu kamu kira bisa melihat sosok seperti mereka itu menyenangkan. Bila ingin mengucap pikirkan terlebih dahulu. Apakah ucapanmu itu menyakiti orang lain atau tidak." (Mega, 2019: 351).

Tuturan tersebut dapat dikatakan sebagai bentuk tuturan yang mengandung makna menyarankan. Hal ini terlihat dari isi tuturan. Agni menyarankan Bella untuk lebih bersyukur karena tidak bisa melihat makhluk tidak kasat mata. Melihat makhluk tidak kasat bukanlah suatu anugerah yang harus dibanggakan karena memiliki risiko, seperti diganggu oleh mereka yang suka jahil atau setiap malam susah tidur. Selain itu, bentuk menyarankan juga dituturkan oleh Agni kepada Bella agar lebih berhati-hati dalam berbicara agar tidak mudah menyakiti orang lain. Ibarat pedang, kata-kata adalah senjata yang paling tajam. Ia bisa melukai hati siapa pun yang mendengarnya sehingga harus berhati-hati ketika berbicara. Efek yang dihasilkan dari tuturan yang disampaikan Agni adalah Bella menjadi pribadi yang lebih berhati-hati, terutama dalam berucap. 


\section{Memaksa}

"Sakit, sakit...," erang Sandra.

Aku terus menekan ujung jarinya dengan sekuat tenaga. Namun, sosok itu tak kunjung keluar, walau dia sudah mengerang kesakitan.

"Keluar dari gadis ini!" suruhku.

"Tidak mau, aku suka bau darahnya," ungkap sang kuntilanak (Mega, 2019: 188).

Kutipan di atas termasuk bentuk tindak tutur direktif memaksa. Pada kutipan tersebut Agni memaksa jin yang merasuki tubuh Sandra keluar. Hal ini dilakukan dengan menekan ujung jari Sandra sambil mengusir jin tersebut agar keluar dari tubuh Sandra dengan mengatakan Keluar dari gadis ini! Jin tersebut tidak mau keluar dari tubuh Sandra karena terlalu suka dengan bau darah menstruasi Sandra. Kutipan di atas terjadi karena Agni ingin menyelamatkan Sandra, rekan sekelasnya yang kerasukan kuntilanak. Kuntilanak tersebut sangat menyukai bau darah yang terdapat di pembalut yang dibuang di tong sampah. Sebelum dibuang, Sandra tidak mencuci bersih pembalutnya sehingga kuntilanak itu menyukai bau darah yang ada di pembalut tersebut hingga akhirnya merasuki tubuh sang pemiliknya. Efek dari tuturan yang disampaikan oleh Agni tersebut adalah hantu yang merasuki sosok Sandra mau pergi dan tidak lagi menganggu dan merasuki Sandra.

"Itu milikku! Kembalikan keris itu! Itu milikku!” (Mega, 2019: 227).

Kutipan di atas terjadi ketika neneknenek penunggu keris yang diambil Dimas menemui Dimas dan Agni. Tak mau keris itu diambil oleh Dimas, nenek tersebut memaksa keris tersebut dikembalikan ke tempat semula. Keris itu bukan milik Dimas sehingga Dimas tidak berhak mengambilnya. Tuturan yang disampaikan oleh nenek tersebut merupakan bentuk tindak tutur memaksa. Sang nenek memaksa Dimas untuk mengembalikan keris yang sudah diambilnya. Efek dari tuturan tersebut sudah jelas, nenek tersebut menginginkan Dimas mengembalikan keris yang sudah diambilnya.

\section{Mengajak}

"Baca doa bareng-bareng yuk, nanti juga makhluk halusnya hilang," suruhnya (Mega, 2019: 288).

Ketika Agni sedang bercengkerama dengan satpam di rumah sakit, tiba-tiba mereka dikejutkan oleh bau amis. Bau amis tersebut keluar dari tubuh Lastri, sosok hantu yang mencoba mendekati Agni dan satpam. Untuk menjaga diri, satpam pun mengajak Agni untuk membaca doa dan meminta perlindungan kepada Tuhan. Hal tersebut tampak pada kutipan Baca doa bareng-bareng, yuk. Kata yuk sendiri setara dengan kata ayo yang artinya mengajak sehingga kutipan di atas merupakan bentuk tindak tutur direktif mengajak. Efek yang dihasilkan adalah Agni mau membaca doa bersama. Dalam tuturan tersebut satpam mengajak Agni untuk berdoa agar bisa mengusir Lastri. Dengan berdoa memohon perlindungan kepada Allah, Agni berharap setan yang mengganggu mereka takut dan lenyap sehingga tidak lagi mengganggunya. Setelah membaca doa, bau amis pun tak lagi tercium.

"Fatih bisa salawatan, kan? Ayo Fatih nyanyi sholawat!" pintaku.

"Nissa baca ayat kursi yah dek, bareng sama mbak Agni." bisa baca ayat kursi Adek bareng Mbak Agni (Mega, 2019: 127).

Meminta perlindungan kepada Allah atau Tuhan adalah sikap yang harus ditanamkan pada diri manusia. Salah 
satu bentuk meminta perlindungan dapat ditunjukkan dengan membaca doa-doa seperti pada kutipan di atas. Dalam kutipan tersebut Agni mengajak kedua adiknya untuk berdoa dan memohon perlindungan kepada Allah dengan membaca selawat dan Ayat Kursi agar wewe gombel yang dilihatnya tidak mendekatinya. Hal ini ditandai dengan kata seru ayo yang memiliki makna mengajak sehingga tuturan di atas termasuk bentuk tindak tutur perlokusi meminta. Dalam tuturan di atas Agni meminta Fatih untuk menyanyikan selawat nabi serta mengajak Nisa untuk membaca Ayat Kursi. Efek yang dihasilkan dari tuturan tersebut adalah Fatih mau menyanyikan selawat nabi dan Nisa mau membaca Ayat Kursi.

\section{Ekspresif}

Tuturan ekspresif merupakan bentuk tuturan evaluasi atau tuturan yang menyatakan sesuatu atas apa yang dirasakannya (Searle dalam Kurniati, 2020). Bentuk tuturan ini ditandai dengan tuturan berterima kasih, meminta maaf, mengucapkan selamat, mengeluh, menyanjung, memuji, dan menyalahkan. Data yang dapat dikategorikan sebagai bentuk tindak tutur ekspresif sebanyak $10,29 \%$. Tuturan ini meliputi permintaan maaf, berterima kasih, memuji, dan mengeluh. Tuturan meminta maaf ditemukan paling dominan pada jenis tuturan ekspresif, sedangkan tuturan mengeluh ditemukan paling sedikit.

\section{Menyanjung}

"Agni, drama You are Beautiful sudah kamu tonton belum?" tanya Deas.

Aku mengangguk. "Yong hwa oppa keren banget."

"Tuh kan, aku bilang juga apa. Dia memang paling keren." (Mega, 2019: 118).
Tuturan di atas merupakan bentuk tindak tutur memuji. Dalam tuturan tersebut Deas memuji Yong Hwa, pemain drama "You are Beautiful", sangat keren.

Wanita tua itu mengangguk. "Ibu tahu, kamu memang anak yang baik, Agni." (Mega, 2019: 157).

Kutipan di atas terjadi ketika acara perpisahan sekolah berlangsung. $\mathrm{Bu}$ Minarti sempat berpamitan dengan Agni sebelum akhirnya harus berpisah. Bu Minarti menyanjung Agni adalah anak yang baik. Buktinya ia membantu Audy mencarikan surat wasiat untuk $\mathrm{Bu}$ Minarti. Tuturan yang disampaikan oleh $\mathrm{Bu}$ Minarti ini mengandung makna sebagai bentuk tindak tutur menyanjung.

\section{Berterima Kasih}

Ibu tersebut mengangguk. "Tadi Annisa juga ke sini buat nyari Fatih, mereka berdua lagi ada di lapangan sepakbola bareng sama anak saya."

"Terima kasih, Bu." Dengan cepat, aku berjalan menuju lapangan yang dimaksud (Mega, 2019: 125).

Kutipan di atas terjadi ketika sore hari menjelang azan magrib berkumandang. Dalam kutipan tersebut diceritakan bahwa Agni sedang mencari keberadaan kedua adiknya yang sedang bermain di lapangan. Ia bertanya kepada seorang ibu yang mengaku bahwa tadi sempat melihat kedua adiknya. Setelah mendapatkan informasi dari ibu tersebut Agni pun mengucapkan terima kasih sebagai bentuk ungkapan menghargai orang yang sudah menolongnya tersebut. Tuturan berbentuk ungkapan terima kasih tersebut termasuk dalam bentuk tindak tutur ekspresif terima kasih. Agni mengucapkan terima kasih kepada seorang ibu karena telah memberi tahu keberadaan adiknya. 
$\mathrm{Bu}$ Minarti mendekatiku dan mulai memelukku. "Terima kasih yah, Agni."

$\mathrm{Aku}$ mengusap punggungnya lembut, pelukan hangat sama seperti pelukan ibuku (Mega, 2019: 31).

Kutipan di atas terjadi ketika Agni berada di UKS. Bu Minarti menemuinya dan berterima kasih karena berkat Audy $\mathrm{Bu}$ Minarti mengetahui pesan terakhir dari anaknya yang sudah meninggal. Kutipan di atas merupakan bentuk ucapan terima kasih dari Bu Minarti. Bu Minarti mengucapkan terima kasih karena telah membantunya untuk menghubungkan pesan Audy dengannya. Ucapan terima kasih dari $\mathrm{Bu}$ Minarti tersebut merupakan tindak tutur perlokusi berterima kasih.

\section{Komisif}

Tuturan komisif merupakan bentuk tuturan yang dilakukan oleh penutur yang diujarkan kepada lawan tuturnya (Searle dalam Kurniati, 2020). Bentuk tuturan ini berupa berjanji, bersumpah, menyanggupi, dan mengancam. Data yang dapat dikategorikan sebagai bentuk tindak tutur komisif pada novel Indigo Strories sebanyak 8,82\%. Hal itu menandakan bahwa tuturan komisif merupakan tuturan yang paling sedikit ditemukan pada penelitian ini. Tuturan yang paling dominan ditemukan ialah menyanggupi, sedangkan tuturan yang sedikit ditemukan ialah berjanji.

\section{Berjanji}

"Kamu harus janji, Agni!"

"Janji apa?"

"Jangan pernah lupain aku."

Aku mengangguk mantap. "Aku janji." (Mega, 2019: 147)

Perpisahan dengan sahabat merupakan hal yang menyedihkan. Setelah Agni pergi, Audy gantung diri. Audy sudah menjadi teman baik Agni di sekolah dan bahkan saling membantu satu sama lain. Akan tetapi, di mana ada pertemuan pasti ada perpisahan. Agni tidak bisa jika harus selalu berada di dekatnya karena Agni sebagai manusia harus melakukan aktivitasnya. Berbeda dengan Audy yang tidak bisa keluar dari kamar mandi sekolah, tempat terakhir ia mengakhiri hidupnya. Alhasil terjadilah perpisahan antara Agni dengan teman hantunya tersebut. Meskipun demikian, Agni berjanji tidak akan melupakan Audy. Hal ini terlihat pada ungkapan Aku janji yang disampaikan oleh Audy. Ungkapan janji pada kutipan tersebut mengandung makna sebagai bentuk tindak tutur berjanji. Agni berjanji kepada Audy bahwa ia tidak akan melupakannya. Efek yang dihasilkan dari tuturan tersebut adalah membuat lega lawan tutur sekaligus sebagai pengikat bahwa Agni tidak akan melupakan Audy.

Aku mengangguk. "Kalian harus janji, yah, jangan kasih tahu soal ini ke siapa pun. aku mohon."

"Janji?" pintaku lagi, sambil menengok ke arah belakang.

Mereka semua mengangguk. "Kita janji Agni." (Mega, 2019: 39)

Kutipan di atas termasuk tindak tutur perlokusi meminta dan berjanji. Tindak tutur meminta dapat dilihat ketika Agni meminta teman-temannya untuk berjanji merahasiakan identitas hantu penunggu kamar mandi (Audy). Hal ini dapat dilihat pada kalimat Kalian harus janji yah, jangan kasih tahu soal ini ke siapa pun dan Aku mohon yang diucapkan oleh Agni kepada teman-temannya. Efek yang dihasilkan dari tindakan ini adalah lawan tuturnya memenuhi keinginan Agni untuk tidak membeberkan rahasia yang akan diceritakan oleh penutur. Tuturan berjanji disampaikan oleh rekan-rekan Agni yang berjanji bahwa dia tidak akan membocorkan rahasia 
yang diceritakan oleh Agni. Tuturan yang disampaikan oleh teman-teman Agni memiliki efek, yaitu mereka tidak akan menceritakan rahasia bahwa Audy adalah anak Bu Minarti pada siapa pun.

\section{Mengancam}

"Kalian mau apa, heh?" tanyaku.

Mereka diam, sambil menunjukkan senyumnya yang menyeramkan.

"Jangan ganggu aku, atau mau aku pukul pake sapu ini" (Mega, 2019: 102).

Ketika Agni tengah tidur malam, tibatiba ia dikejutkan oleh kedatangan dua sosok tuyul. Mereka menganggu tidur nyenyak Agni, menarik selimut, menjatuhkan buku-buku yang tertata rapi di rak hingga menjatuhkan remote AC. Agni pun berlari menuju ke dapur hingga terpeleset karena lantai yang licin. Tuyul-tuyul itu masih saja tertawa menggoda Agni dan menunjukkan rasa ketidaksukaannya kepada Agni. Karena kesal, Agni pun mengancam akan memukul tuyul-tuyul tersebut dengan sapu jika menganggu Agni dengan mengatakan Jangan ganggu aku, atau mau aku pukul pake sapu ini. Tuturan Agni tersebut merupakan bentuk tindak tutur mengancam. Dalam kutipan tersebut Agni mengancam tuyul-tuyul jahil yang menggodanya. Agni mengancam akan memukulnya dengan sapu jika tuyul-tuyul itu tidak mau pergi dan tetap menggoda Agni. Efek yang dihasilkan dari tuturan tersebut adalah membuat tuyul-tuyul itu takut kemudian pergi dan tidak lagi menganggu Agni.

Aku menatapnya dengan tatapan tajam. "Kau ingin diusir dari tempat ini, jika kau terus mengganggu orang lain. Aku tak mau lagi berteman denganmu lagi. Ingat itu," ancamku (Mega, 2019: 50)

Tuturan tersebut termasuk tindak tutur mengancam. Hal itu dapat dilihat dari verba ancamku sebagai penanda penutur pada kalimat langsung tersebut. Hal itu menandakan bahwa tuturan yang disampaikan Agni bermaksud mengancam. Agni mengancam kepada Audy bahwa ia tidak ingin berteman lagi dengannya jika masih suka usil dan menganggu orang lain. Audy merupakan hantu yang jahil dan suka mengganggu manusia. Ia adalah salah satu teman Agni di sekolah, tetapi Agni tidak suka dengan sifat Audy yang suka menjahili manusia. Ia pun mengancam Audy jika masih memgganggu manusia, dia tidak mau lagi berteman dengannya. Efek yang dihasilkan dari tuturan tersebut adalah lawan tutur atau Audy tidak usil lagi menganggu kehidupan manusia, terutama siswa di sekolah.

\section{Menyanggupi}

"Jangan menganggu dulu yah, aku sedang fokus bekerja. Nanti bila ada waktu luang, aku akan mengajakmu bermain," aku berbicara tepat dihadapan jongen (Mega, 2019: 325).

Bukan hanya sosok hantu merah yang menyeramkan, di tempat kerja Agni juga ada sosok anak kecil usil keturunan Belanda. Keusilannya tersebut didasari keinginan bermain dengan Agni. Namun, Agni tidak bisa meladeninya setiap hari karena harus bekerja. Kepada Jogen, Agni pun menuturkan bahwa selepas pekerjaannya selesai pasti ia akan bermain bersamanya. Tuturan Agni yang demikian mengandung bentuk tindak tutur menyanggupi. Tuturan tersebut menghasilkan efek membuat lega Jogen sehingga dia tidak menganggu selama Agni bekerja.

"Sudahlah, Ibu mau masuk kamar. Kamu harus tidur, sudah mau jam 12 malam, jangan sampai bapak kamu tahu kamu belum tidur, bisa dimarahi."

"Iya Bu, sebentar lagi" (Mega, 2019: 454). 
Ketika Agni dan ibu sedang menonton tv, Agni mendengar suara gedoran dari balik pintu. Ia bercerita kepada ibunya, tetapi ibunya tidak percaya. Ibunya pun menyuruh Agni untuk bergegas tidur mengingat waktu sudah menunjukkan pukul 12 malam. Agni pun membalas tuturan ibunya dengan frasa $I y a B u$, sebentar lagi. Tuturan yang disampaikan ibu termasuk bentuk tindak tutur meminta. Efek yang dihasilkan adalah Agni bergegas untuk tidur dan istirahat mengingat waktu sudah larut malam. Tuturan yang disampaikan oleh Agni mengandung bentuk tindak tutur menyanggupi. Agni menyanggupi perintah ibunya untuk masuk ke kamar dan bergegas istirahat.

\section{Deklaratif}

Tuturan deklaratif merupakan bentuk tuturan yang mengubah keadaan (Searle dalam Kurniati, 2020). Tuturan ini ditandai oleh tuturan yang mengandung makna melarang, memutuskan, dan mengizinkan. Data yang dikategorikan sebagai bentuk tindak tutur deklaratif pada novel Indigo Strories sebanyak $6,25 \%$. Pada tuturan deklaratif hanya ditemukan bentuk tuturan melarang.

\section{Melarang}

Mendengar keributan dari luar, Julian langsung menengok keluar. Ia mendengar sang papa berteriak, "Jangan Irina, kumohon jangan lakukan itu. Sadarlah, kau ini seorang ibu." (Mega, 2019: 334).

Nurmadji dan Irina merupakan pasangan suami istri dan memiliki anak bernama Julian. Nurmadji berdarah pribumi dan Irina berdarah Belanda. Irina ingin menikah dengan Nurmadji karena kekayaannya. Namun, setelah dikaruniai buah hati yang menginjak usia lima tahun, kekayaan Nurmadji menurun drastis. Irina tidak ingin hidup susah. Bahkan, dari hari ke hari ia kehilangan akal sehatnya. Ketika Irina mendengar kedatangan tentara Nippon yang terkenal kejam sudah mendarat di tanah air, ia malah ingin kembali ke Belanda sendiri tanpa memikirkan nasib Nurmadji dan Julian. Nurmadji tidak mengizinkan Irina kembali ke Netherland dengan alasan Julian masih kecil. Ia butuh kasih sayang dari seorang ibu.

Irina menyiapkan tambang dan memanggil Julian. Irina menggantung anaknya hingga kesulitan bernapas dan akhirnya mati. Dengan demikian, ia sudah tidak perlu lagi memikirkan nasib Julian. Sebelum pembunuhan terjadi, Nurmadji sudah mencoba untuk melerai keinginan Irina. Hal itu dapat dilihat pada kutipan di atas bahwa Nurmadji mencoba untuk melerai maksud hati Irina untuk membunuh Julian. Nurmadji mencoba melarang Irina dengan kalimat Jangan Irina, kumohon jangan lakukan itu. Sadarlah, kau ini seorang ibu. Tuturan Nurmadji tersebut dapat dikatakan sebagai bentuk tindak tutur melarang. Nurmadji melarang Irina yang akan membunuh anaknya. Efek yang dihasilkan dari tuturan tersebut ialah Irina atau lawan tutur melerai perbuatan kejinya tersebut. Namun, sayangnya Irina tidak memperhatikan kalimat Nurmadji dan nekat membunuh Julian.

Andini langsung melepaskan tangan Wira yang kala itu tengah membelai wajahnya. Ia menatap Wira nanar. "Jangan kau lakukan hal itu, jangan kau buat hidup kita samasama menderita. Aku memang masih memiliki perasaan padamu. Namun kau seperti ini, kau hanya akan melukai perasaanku saja. Lebih baik kita seperti ini, saling mengagumi dan mencintai dalam diam." (Mega, 2019: 470)

Tuturan tersebut mengandung bentuk tindak tutur melarang. Dalam tuturan tersebut Andini melarang Wira yang 
berniat untuk membunuh raja atau suami Andini. Diceritakan dalam novel bahwa Wira sangat mencintai Andini. Akan tetapi, ayah Andini tidak menyetujui jika putrinya menikah dengan anak seorang pembunuh sekaligus musuh bebuyutannya. Andini pun dinikahi oleh sang raja. Rasa cinta yang tulus dari Wira masih ada di benaknya. Ia masih mencintai Andini, bahkan berniat membunuh sang raja berharap agar Andini mau menikah dengannya. Akan tetapi, Andini melarang maksud hati Wira tersebut seperti pada kalimat Jangan kau lakukan hal itu. Tuturan tersebut merupakan bentuk kalimat larangan yang disampaikan oleh Andini kepada Wira. Andini melarang Wira untuk membunuh suaminya. Efek yang dihasilkan dari tuturan tersebut adalah Wira mengurungkan niatnya untuk membunuh sang raja.

\section{PENUTUP}

Tindak tutur perlokusi merupakan tuturan yang bertujuan untuk memengaruhi kawan tutur. Adanya bentuk tindak tutur bertujuan agar kawan tutur melakukan apa yang disampaikan oleh penutur. Novel sebagai salah satu jenis karya sastra memuat bentuk tuturan yang hampir sama dengan kehidupan manusia pada umumnya. Hal ini didasari oleh kenyataan bahwa karya sastra merupakan cermin kehidupan manusia sehari-hari dalam berinteraksi dengan lingkungan.

Berdasarkan analisis, penulis menyimpulkan bahwa tindak tutur perlokusi yang terdapat dalam novel Indigo Stories meliputi tindak tutur representatif, direktif, ekspresif, komisif, dan deklaratif. Bentuk tuturan representatif ditemukan sebanyak $36,76 \%$, meliputi bentuk tindak tutur menyatakan, mengakui, dan menunjukkan. Pada bentuk tuturan ini jenis tuturan yang paling banyak ditemukan ialah menyatakan.

Bentuk tuturan direktif ditemukan sebanyak 37,86\% meliputi bentuk tindak tutur meminta, mengajak, memaksa, dan memohon. Pada tuturan ini yang paling banyak ditemukan adalah tuturan meminta.

Tuturan ekspresif ditemukan sebanyak 10,29\%, meliputi bentuk tindak tutur mengeluh, berterima kasih, dan memuji, sedangkan tuturan yang paling banyak ditemukan adalah mengucapkan maaf.

Tuturan komisif ditemukan sebanyak $8,82 \%$, meliputi bentuk tindak tutur berjanji dan menyanggupi. Pada tuturan ini tuturan menyanggupi paling banyak ditemukan. Tuturan deklaratif ditemukan sebanyak $6,25 \%$ meliputi bentuk tindak tutur melarang.

\section{DAFTAR PUSTAKA}

Achsani, F., \& Hilmi, M. M. (2018). Campur Kode dalam Komunikasi Santri di Pondok Pesantren AlHikmah Sukoharjo. Jurnal Kajian Bahasa, Sastra Dan Pengajaran (KIBASP), 2(1), 24-37. https://doi.org/10.31539/kibasp.v2i 1.347

Astuti, S. B., \& Retnosari, I. E. (2016). Tindak Tutur dalam Talkshow Hitam Putih di Trans 7. EDUKATA, 3(2), 101-110.

Huwaida, S. T., Fransiscus, X. S., \& Imam, B. (2020). Tindak Tutur Direktif dalam Novel Wigati Karya Khilma Anis sebagai Materi Ajar Kebahasaan Teks Prosedur di SMA. Repetisi: Riset Pendidikan Bahasa dan Sastra Indonesia, 3(1), 77-89.

Kurniati, A. (2020). Tindak Tutur Ekspresif dalam Novel My Stupid Bos 5 Karya Chaos@Work. Suar Betang, 14(1), 45-58. 
Marini, N., \& Rizki, R. P. (2021). Tindak Tutur Ilokusi pada Novel "Guru Aini" Karya Andrea Hirata. Genta Mulia, 12(1), 245-251.

Marwuni, W. T., \& Asep, P. Y. U. (2020). Analisis Tindak Tutur Ilokusi di Cuitan Akun Twitter @Sudjiwotedjo pada Bulan Februari 2020. Kadera Bahasa, 12(1), 23-33.

Mega, H. (2019). Indigo Stories. Coconut Books.

Nursiah, \& Siti, A. L. (2020). Tindak Tutur Ekspresif dalam Novel Bumi Manusia karya Pramoedya Ananta Toer. Jurnal Lingua Susastra, 1(2), 73-81.

Polanda, M., \& Putri, N. (2020). Analisis Tekstual dan Kontekstual Naskah Novel Al-Khubzh Al-Hafiy Karya Muhammad Syukri. Diwan: Jurnal Bahasa dan Sastra Arab, 6(1), 33. https://doi.org/10.24252/diwan.v6i 1.12153

Puspasari, D. (2020). Baca Cerita Horor di Twitter, Penasaran Mengalahkan Ketakutan. Kompasiana.

Putra, K. S., Fitriyanti, Bungab, \& Alif, A. (2020). 5 CM dari Novel ke Film: Kajian Ekranisasi dan Perbandingan Struktur. Multilingual, Vol., 9(2), 161-174.

Rahmawati, E., \& Ferdian, A. (2019). Nilai-Nilai Moral Novel Peter Karya Risa Saraswati dan Relevansinya dengan Pembelajaran Bahasa Indonesia. Lingua Franca: Jurnal Bahasa, Sastra, dan Pengajarannya, 3(1), 52-64.

https://doi.org/10.30651/lf.v3i1.24 35

Sanyya, E., Triana, L., \& Anwar, S. (2020). Tindak Tutur Imperatif dalam Caption Akun Teladan Terhadap Pembelajaran Bahasa
Indonesia di SMA. Jurnal Penelitian Pendidikan Indonesia, 5(2), 1-8.

Sari, I. P., \& Irma, C. N. (2020). Analisis Tindak Tutur Ekspresif dalam Acara Seminar Mario Teguh Terbaru 2019. Hasta Wiyata, 3(2), 47-53.

https://doi.org/10.21776/ub.hastaw iyata.2020.003.02.05

Sari, I. R. (2014). Analisis Pragmatik Pelanggaran Tindak Tutur Guru di SMA Lentera. Pena, 4(1), 37-50.

Sultoni, Achmad, \& Kaleb, E. S. (2020). Persoalan-Persoalan Sosial dalam Novel Pasung Jiwa Karya Okky Madasari. MEDAN MAKNA: Jurnal Ilmu Kebahasaan dan Kesastraan, 18(1), 107. https://doi.org/10.26499/mm.v18i1 .2344

Tamrin, \& Nursyamsi. (2020). Bentuk Tindak Tutur Direktif dalam Interaksi Jual Beli Di Pasar Tradisional Kota Palu. Multilingual, 19(1), 18-31. https://doi.org/10.26499/multilingu al.v19i1.139

Umamy, F., \& Cintya, N. I. (2020). Analisis Tindak Tutur Direktif dalam Novel Orang-Orang Biasa Karya Andrea Hirata. Bahtera: Jurnal Pendidikan, Bahasa, Sastra, dan Budaya, 7(1), 782791.

Wijana, I. D. P., \& Muhammad, R. (2011). Analisis Wacana Pragmatik: Kajian Teori dan Analisis. Surakarta: Yuma Pustaka. 